Saudi Journal of Business and Management Studies Abbreviated Key Title: Saudi J Bus Manag Stud ISSN 2415-6663 (Print) |ISSN 2415-6671 (Online) Scholars Middle East Publishers, Dubai, United Arab Emirates Journal homepage: https://saudijournals.com

Review Article

\title{
Design Diversity and Brand Loyalty
}

\author{
Ahmet Atak ${ }^{1 *}$ \\ ${ }^{1}$ Gazi University, TUSAŞ Kazan Vocational School, Emniyet mah, Gazi Üniversitesi Rektörlüğü, Bandırma Cd No:6/1, 06560 \\ Kahramankazan /Ankara, Turkey
}

\begin{tabular}{ll}
\hline DOI: $10.36348 /$ sjbms.2021.v06i03.002 & | Received: 14.02.2021 | Accepted: 10.03.2021 | Published: 16.03 .2021 \\
*Corresponding author: Ahmet Atak & \\
Email: ahmetatak@gazi.edu.tr &
\end{tabular}

\section{Abstract}

In the realm of beings, human beings by their nature, are never satisfied with one kind of product and are always on the lookout for difference and innovation. When the world of animals is observed, for example, it can be seen that they are beings who never tire of eating grass or doing the same thing for life. Besides, they do not have multiple options. When the plants are observed, the situation looks similar; they consume soil for life and perform photosynthesis. Thanks to their mind and consciousness, people are equipped with the ability to compare, decide if they like or dislike, and want to pick or not pick the things they encounter. However, when these abilities face limited options, it's easy to get stuck in a difficult situation; They may also choose an option such as not preferring anything. It is also possible that they will search for an alternative. It is thought that the ability of people to prefer this or similar way may have a negative impact on customer loyalty to the brand and product. On the one hand, while producers want to increase their market shares by keeping the product range suitable for each consumer profile in terms of marketing, the consumer who faces the situation of choosing one among the diversity may have difficulty in choosing. For instance, which one of the cell phones, which of the televisions, which of the computers, which of the cars, etc. In fact, what is in question is how a product's design appeals to different consumer profiles in different ways. The customer buys a product whether he/she knows it and it fulfills his/her needs and aspirations, in other words, whether he/she likes it. Even if he/she does not purchase the product, he/she can preserve consumer loyalty by comparing the design innovations produced in the one he/she bought to the current version. However, when the customer cannot decide between different product designs that appeal to various customer profiles, he/she may lose his/her loyalty to the brand and switch to another product. This will have a detrimental effect on the product's marketing plan, and sales may decrease as a result. In this study, in terms of customer loyalty, the questions of: "Does a customer have the patience and time to choose without getting tired in the face of the variety of designs that appeal to different customer profiles in the same product?", "Will the customer still remain loyal?", "What solutions are there for the continuation of loyalty?" have been analyzed and researched. In other words, it was discussed what kind of relationship might exist between design and product diversity and customer loyalty. At the same time, the effect of low or no free time, unwillingness to collect information to evaluate products and to assess them for a long time on brand and product loyalty has been examined.

Keywords: Design Diversity; Brand loyalty; Customer loyalty; Re-purchasing behavior.

Copyright (C) 2021 The Author(s): This is an open-access article distributed under the terms of the Creative Commons Attribution 4.0 International License (CC BY-NC 4.0) which permits unrestricted use, distribution, and reproduction in any medium for non-commercial use provided the original author and source are credited.

\section{INTRODUCTION}

Customer loyalty, also known as brand loyalty, occurs when a customer is satisfied with a product that he/she purchased and preferred the same or another product from the same brand that is innovative. Various studies and surveys are used to measure the possibility of consumers switching to another brand, as well as to determine consumer loyalty. In other words; as the customer's brand loyalty increases, their tendency towards other competing products decreases [1].

"There is a relationship between brand loyalty and the perceived risk of purchasing the product. In addition to reducing the perceived risk in purchasing, brand loyalty causes the consumer to collect less information and spend less time evaluating brands in the purchasing process" [1]. On the other hand, today's 
Ahmet Atak., Saudi J Bus Manag Stud, Mar, 2021; 6(3): 56-60

lack of free time, as well as an unwillingness to gather information to evaluate the product and submit it to extensive testing, could cause the customer to abandon the product. Product diversity by design can harm brand loyalty by extending the customer's decision time and causing indecision. Allowing customers to make decisions quickly and without wasting too much time can help them maintain their commitment to the product.

There are also many other terms such as "repeat purchasing behavior", "preference", "loyalty" or "keep buying" used instead of brand loyalty.

Customer Loyalty is a concept that has started to take place in the marketing literature in recent years related to technological and economic developments. In the rapidly developing GSM sector, the most important basic condition for an operator firm to protect its existing customer portfolio from its competitors is to ensure customer loyalty. Customer loyalty is one of the essential elements for a company to survive in the long term.

Another concept related to our topic is "involvement" in the product. "Involvement, which is a personal interest in the self-interests of the individual, forms the basis of the person-object relationship. Besides, it is the only explanatory of the relationship between consumer and product category. It is the general level of interest in the object. In other words, when the object of interest is perceived as important in meeting the needs, goals, and values of the individual, the consumer becomes related to the product" [2].

The fact that the products are designed and presented in large numbers regarding various consumer profiles means that the interested person has information about all these types and has sufficient time. This increases the fear or risk of purchasing the wrong product and can damage loyalty to the brand. Involvement is covered in four different aspects; purchase decision involvement or situational involvement, product class involvement or sustained involvement, response involvement, and advertising message involvement. In terms of design diversity, the relation of involvement with the first and second aspects is more important for the topic of this study. The fact that design changes and diversification are comprehensible and beneficial for the customer can accelerate the purchasing decision of the customer and if the products he/she is interested in can also be classified, the place of the product in the customer will become clear, and again the continuity of product loyalty will be ensured. In the opposite case, the involvement may be reduced or even ruptured in an undesirable way.

As a result of various researches, it has been revealed that consumers show multi-brand loyalty in fast-moving consumer goods. Multi-brand loyalty is when the consumer purchases out of more than one brand that he/she finds acceptable. Multi-brand loyalty is also called split loyalty. It has been suggested that buying behavior in fast-moving consumer goods is made because it has become a habit and the purchasing decision process is not effective, and attitudinal criteria will not work, especially in established markets [3]. For these accustomed fast-moving consumer goods, the customer purchases multiple selections consistently, with shared loyalty as long as there is no problem. Therefore, the customer is often engaged and loyal to a variety of products. Design diversity is desirable in such fast-moving consumer goods. However, product diversification by nature is acceptable up to a certain number of goods that are purchased over a long period of time, but if it becomes too diversified, the customer's loyalty cannot be separated, and it can even lead to a loss of loyalty.

Another relevant subject is the "selection set theory" which is the subject of Dölarslan, E. Ş.'s research. Dölarslan in his research made evaluations in terms of consumer purchasing decision process in relation to selection set theory and thinking set [4]. The consumer first creates a selection set for the brands related to the product to be purchased and then, in the second stage, they create thinking set and select from those sets. It can be called as a kind of access to the selection through gradual elimination method. It is thought that this method will have a positive impact on brand loyalty by growing the customer's interest in the product and marketing it by considering the design diversification of the product and other auxiliary product designs.

Another related subject is brand and branding strategies. A brand is the name of symbolizing a company, a product. As in the case of "Coca-Cola", the company's main capital is largely comprised of its name. A brand is more than just a logo or a name; it expresses the feelings and thoughts of the consumer about the company and its products. Apart from the shape, structure, and packaging of the product; the way the consumer perceives the product and how he/she positions it in his/her mind is included in the concept of the brand" [5].

\section{Product classification from the customer point of view}

Products are divided into four groups based on "how" their consumers buy them:

1. Convenience goods

2. Preferential goods

3. Speciality goods

4. Unsought goods

Convenience goods; they are goods that are often or urgently purchased, are low priced, without 
much effort to buy, or with a large number of outlets. E.g .: rice, sugar, chocolate, toothpaste.

Preferential goods; goods that are purchased less frequently, have higher prices, fewer places of sale, or are comparatively purchased. E.g.: furniture, clothing, household items.

Speciality goods; they are products that consumers make a great effort to buy, have high prices, have unique features, are important for brand identification or have a small number of sales points. Eg: Rolex watches, cars, computers.

Unsought goods; are innovations, products that consumers do not intend to buy, or goods that require more advertising and personal selling. Eg: life insurance, tombstone, blood donation.

\section{Individual product decision factors}

The product itself and its features are also called the core product, and the side effect factors that affect the product decision can be listed as follows:
1. Product features,
2. Branding,
3. Packaging,
4. Labeling,
5. Product Support Services

Product features; which are the features of the product itself, Quality (TQM, ISO 9000, ISO 14001),

Design (Design thinking, Universal design, Human-oriented design, Recyclable design),

Brand (a name, symbol, shape, or a combination of these that determines the identity of the brand, goods, and services, distinguishes it from competitors)

Packaging and labeling (It is the covering of the goods in order to ensure their use, transportation, and protection.) they can be listed as above.

When consumers shop on your web for the first time, they may be mainly inspired by the site's design and product images. Therefore, it may be useful to give importance to these features. However, the customer who is not satisfied with the product quality may not be loyal to your brand. With just a good design and visuals, it may not be possible to impress customers more than once.

Packaging, labeling, and product quality are all critical elements in establishing a brand and maintaining customer loyalty, particularly in the long term.

Before moving on to branding, the designproduct-customer loyalty relationship will be examined.
3. Design, Diversification by Design and product loyalty

One could say that design is actually the main identity of a product. Design is the basic element that determines the unique features of the product. The design of the product is the most important aspect that makes that product talk, defines its relationship with the customer, the why and how of the product, even its life story, its death and its resurrection in another product. Design is now a very comprehensive process and is seen as a branch of science that comes into play at every stage of the product and is taught as a major discipline in universities under the name of "industrial product design".

Undoubtedly today, it has emerged as a fact; companies that take customer requests and needs into account and design products that are compatible with the changing market conditions and technological changes can be assertive in the market [6].

A new product designattacts one's interets because of his/her curiosity and wants to understand the new product. Approaches the product with questions such as why it is made, what is it for, how it works. If the customer seeks and finds answers to these questions in product design, his/her relationship with the product begins and product and brand loyalty begin to shape bit by bit. He/she then takes ownership of the product and boasts of it, and even takes and uses it as a show-off material. Since human beings are tired of a monotonous life and desire changes; stepwise improvements in design during specific times can have a positive impact on them. On the other hand, brands that do not make changes for a long time may become destined to be forgotten one day. The new product design, which takes into account the changing customer demands and requirements in accordance with the market requirements and conditions of the manufacturing organizations, has gained more importance today. However, very sharp design changes can damage customer loyalty due to the habit of the product. Therefore, after creating the brand acceptance in the customer, it may be more appropriate to make the design changes step by step and by acclimatizing the customer.

While diversifying the design of a limited number of products in the same brand can have a positive effect on the customer, too much product design diversity may cause the customer to ignore all of those products and eventually disconnect from that brand, as the customer prefers the easier way. In other words; the product with a changed design has changed must find a place in the customer and settle in his/her prior information system like a puzzle piece. For example, orange, tangerine, lemon have a place in human knowledge and senses and immediately provide the customer's relationship with the product. However, since a product that is "like an orange" or "like a 
Ahmet Atak., Saudi J Bus Manag Stud, Mar, 2021; 6(3): 56-60

tangerine" but not exactly either of them, can not find a place in the customers and their senses immediately, the relationship with the product can be very difficult or get complex. It prevents the customer from purchasing this new product. Unreasonable and unnecessary variety in product diversification, which cannot be answered to questions such as why and how, may create negative effects on the customer, and this time, a product that he/she is satisfied with may cause him to lose interest in the brand.

However, design diversification; by being designed in a way that the customer can perceive, it can ensure the continuity of the customer's relationship with and loyalty to the product. Similarly, subtle modifications to the product make it more useful. Another method suitable for making the product diversification by design understandable; is being able to offer various utility comparative services. As an example, a chart comparing the design, or a computer program that can be viewed on the Internet that can make a small selective comparison can be presented. There are already internet portals regarding phone, television, and car selection, where users can obtain comparative charts for the products they want.

In fact, the design is not something that only concerns the product itself. It necessitates the design of the product's packaging, its brand, its life story, the final product's design, and even the interaction between the product and the customer, in addition to the product itself.

In addition, in this study, we will try to examine how a strong brand design should be made, which is the most important factor besides the good design of the product, and which strategic factors are important in brand design and creation.

\section{Strong brand design and development}

The name or the logo of the brand constitutes an important stage in product design as it is a descriptive, identifying mark of the brand [6]. Brand design and brand value creation are also one of the most crucial factors in marketing. People generally adhere to certain brands and prefer goods from those brands. Brand Value; denotes that brand recognition has a positive differentiating impact on the customer's response to the product and that in all situations, customers prefer the company's product to the competitors' product. This leads to greater brand awareness, loyalty, and strong profitable customer relationships. The main decisions to be taken in creating a brand value are as follows:

1. Brand positioning, Brand name selection,

2. Brand sponsorship,

3. Brand development

Brand positioning occurs at three levels: 1. Product features,
2. Benefit from the product and

3. Beliefs and values

Brand Name Selection is done by paying attention to the following factors:

1. It should be easy to pronounce and remember,

2. It should be distinctive,

3. It should reflect the product features and quality,

4. It should be easily translated into foreign languages.

\section{Brand Development;}

1. Producer brand or national brand (Yayla rice),

2. Private brand or intermediary brand (Migros rice),

3. Licensed brand (Lacoste),

4. Brand Partnership (Co-branding; TOYOTASA, HITONSA)

Line widening: It is the introduction of products with new features in the same product class under the same brand name. (For example, Separate packaging for strawberry, banana, chocolate cupcakes of Eti, Halley, Nestle fruit milk, Coca Cola (Light, Zero, Normal).

Brand expansion: Presenting a new or renewed product with the same (successful) brand name in an existing product class. Johnson - baby shampoo, soap, cologne)

Multiple Brand: Using new products in the same product class. Eg, Eczacıbaşı-Nivea, Solo, Selpak

New Brand: It can be used when the strength of the existing brand is reduced or when a new brand name is needed. For example, changing the name of the restaurant although the operators of a restaurant are the same; Turkish show host Okan Bayülgen's programs in the same format change their names from time to time: Zaga, TV Boy.

As can be seen, a brand design goes through a certain process on its own and requires a wide variety of specified decisions. Besides, the brand's creation of the desired perception in the customer and making this perception sustainable are other important factors.

\section{CONCLUSION EVALUATION}

It has been revealed that the design of a product is not just a change in physical appearance, but plays an effective role in the entire product life, from the idea, design, production, packaging, advertising, branding, and to reusability in a new product.

Here, concepts such as customer loyalty, product loyalty, brand loyalty, and the concepts of design that affect product loyalty are explained and the relationship between design and product variety and 
customer loyalty is discussed. Both the product's own design and the brand design and the factors affecting them have been tried to be addressed in terms of customer loyalty.

It has been concluded that product diversity with a certain number of designs may create a positive perception of the customer product loyalty, as well as a negative effect on the customer's loyalty in the face of the difficulty of comparing and choosing due to the abundance of this variety. The limit for the number of varieties may be different for each product and should be evaluated differently. Maybe a classification can be made.

Some solution recommendations have been proposed, such as comparison software programs, to ensure that product diversity with a wide variety of designs does not have a negative impact on customer loyalty.

What is discussed here is that the effect of product diversity by design on customer loyalty or product loyalty can be determined by experimental researches that can be done in what numbers and what kind of effect it will have when the number of product types are taken as basis.

\section{REFERENCES}

1. Gul Bayraktaroglu, G. (2004). Factors Affecting Brand Loyalty in Convenience Goods: A Study on Instant Coffee. Management and Economy-2004, Celal Bayar University, 11(2).

2. Cilingir, Z., \& Yildiz, S. (2010). The Effect of Consumers' Involvement in Products on Brand Loyalty: Pilot Study in Istanbul for a Symbolic Product Group. ZKU Journal of Social Sciences, 6(11), 79-100.

3. Demir, M. O. (2012). Measuring brand loyalty: Comparison of intention-based attitudinal scale and behavioral scale based on purchase order. Journal of Istanbul University Faculty of Management, 41(1), 103-128.

4. Dolarslan, E. Ş. (2012). Consumer purchasing decision process within the framework of selection set theory. Eskisehir Osmangazi University Feas Journal, 7(1), 7-37.

5. Kirda, R. Y. Establishing Brand Strategies - The Coca-Cola example, Review of Social, Economic \& Business Studies, 3(4), 233-250.

6. Ozdil, T. I., \& Yılmaz, C. Y. (2005). Factors Affecting Consumer Preferences in Selected Products. Selcuk University Karaman Journal of Economic and Administrative Sciences, 2(5). 